\title{
PREVENTION OF SUBINVOLUTION OF THE UTERUS OF COWS USING ACIDUM SUCCINICUM
}

\author{
Larysa Fedoniuk, Yaroslav Stravskyy, Vira Khavtur, Roman Sachuk
}

\begin{abstract}
Aim. To establish the effect of acidum succinicum on the activity of enzymes in the blood of cows after calving and the course of uterine involution.

Materials and Methods. The study of enzyme activity was carried out in the Central Research Laboratory of I. Horbachevsky Ternopil National Medical University (Certificate of technical competence № 001/18, issued on September 26, 2018, valid until September 25, 2023).

Results of the research. After the use of acidum succinicum in the body of cows of the experimental group, the activity of alanine aminotransferase increased by $12,0 \%(p \leq 0,05)$, and the activity of aspartate aminotransferase, on the con-

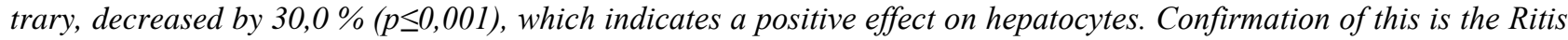
factor, which increased 1,4 times $(p \leq 0,05)$.

All animal experiments were conducted according to with the recommendations of ARRIVE and the British Animal Act 1986 and Directive 2010/63 / EU on the protection of animals for scientific investigation.

In the body of cows of the control group, the activity of alanine and aspartateaminotransferases increased, respectively, by $14,0 \%(p \leq 0,05)$ and $47,0 \%(p \leq 0,001)$ against a background of a 1,2-fold decrease $(p \leq 0,05)$ Ritis factor.

A decrease in bilirubin content of $56,0 \%(p \leq 0,001)$ in the body of cows after the use of acidum succinicum and an increase in its content by 2,2 times $(p \leq 0,001)$ in the body of control cows indicates liver disease, which is accompanied by affection of its parenchyma, which may be a consequence of intoxication of their body in the last trimester of pregnancy.

Conclusion. Acidum succinicum, applied to cows after calving, prevents the development of inflammation of the reproductive system, helps to restore reproductive function, reduces the duration of the service period to 80,0 2,0 days, and the insemination index to 1,3
\end{abstract}

Keywords: cows, calves, enzymes, acidum succinicum, subinvolution of the uterus

How to cite:

Fedoniuk, L., Stravskyy, Ya., Khavtur, V., Sachuk, R. (2021). Prevention of subinvolution of the uterus of cows using acidum succinicum. ScienceRise: Biological Science, 2 (27), 49-52. doi: http://doi.org/10.15587/2519-8025.2021.235936

(C) The Author(s) 2021

This is an open access article under the Creative Commons CC BY license

\section{Introduction}

Keeping productive animals with modern technological methods of stockbreeding on the background of unbalanced feeding creates the preconditions for the development of immobilization stress, which leads to secondary metabolic disorders, reduced nonspecific resistance and, as a consequence, the development of obstetric pathology $[1,2]$.

The most sensitive to the development of pathologies are highly productive cows. It has been established that in cows the physiological course of pregnancy is accompanied by intensification of lipid peroxidation, the products of which have a destructive effect on cell membranes and intracellular biopolymers [3, 4]. At the same time, the level of antioxidant protection in pregnant cows decreases, under stress the balance in the system of "lipid peroxidation - antioxidant protection of the body" is disturbed, which is a prerequisite for the development of pathological conditions [5].

Uterine involution in cows should not exceed 30 days. However, the results of many studies and data from veterinary practice show that in a large number of animals this process is significantly delayed, which indicates the need to stimulate the involution of the reproductive system as an important measure in the system of prevention of postpartum complications.

The use of immunomodulators of isamben and regenerative biostimulator in cows before and 1-2 per day after birth allowed to effectively correct in a positive direction the immunodeficiency of the body and stimulate the involution of the reproductive system [6]. Intraabdominal use at the end of the postpartum period of caplaestrol and clalagonine reduced the duration of the period from birth to the first stage of sexual arousal by 40 and 34.4 days, respectively [7].

Injection of $20 \%$ vinyl solution to cows in the uterus in a mixture of $0,2 \mathrm{~g}$ of Aethacridini lactas from the first day of the postpartum period with an interval of 48 hours and intramuscularly $2 \mathrm{ml}$ of $0,1 \%$ solution of carbocholinum or $0,5 \%$ prozerin prevented the development of postpartum metritis [8, 9]. Administration of ligofol, placental extract parenterally at a dose of 5,0 ml 
10-15 days before delivery, on the day of delivery and during sexual hunting contributed to the physiological course of the postpartum period and fertilization in $57,5 \%$ of cows after the first insemination, the use of intrauterine selemag, sapropel extract at a dose of $300 \mathrm{ml}$ in $100 \%$ of cases prevented the retention of manure [10, 11]. Much work has been devoted to the use of supplements of amber-scorbin, tetravit, selenium, vitamin E $[12,13]$. Intravenous administration of a mixture of $40 \%$ glucose and $5 \%$ ascorbic acid to cows in the first stage of labor activated the course of calving and involution of the uterus $[14,15]$.

There are very few reports in the literature on the use of acidum succinicum in the prevention of subinvolution of the uterus of cows. At the same time, acidum succinicum is a strong antioxidant, very effective in the body, and directed mitochondrial action. Acidum succinicum is a substance of natural origin that helps to normalize the overall metabolism in the body and has a wide range of biological effects: stimulates energy metabolism in body cells, significantly improves cellular respiration, has an antihypoxic effect; promotes the excretion of toxic substances (both endogenous and exogenous); activates immunity; improves the body's adaptation to the negative effects of the environment; has tonic and restorative properties [16].

Aim of the study was to establish the effect of acidum succinicum on the activity of enzymes in the blood of cows after calving and the course of uterine involution.

\section{Materials and methods}

Research was conducted in 2019. At the preparative stage, experimental $(n=10)$ and control $(n=10)$ groups of animals were formed. Cows, Ukrainian blackpiebald breed, aged 4-5 years, were selected according to randomization technology - assigning experimental animals to groups by random sampling, which minimized statistical errors.

Cows of the 1 experimental group were administered intramuscularly acidum succinicum at a dose of $10,0 \mathrm{ml}$ per animal on the day of calving and three times in a row with an interval of 48 hours. Saline at a dose of
$10,0 \mathrm{ml}$ per animal on the day of calving and three times in a row with an interval of 48 hours.

Before and after the using of drugs, cows blood was taken for biochemical studies. Blood was taken in accordance with the rules of asepsis and antiseptics from the jugular vein in cows before morning feeding.

The study of enzyme activity was carried out in the central research laboratory of I. Horbachevsky Ternopil National Medical University (Certificate of technical competence No. 001/18, issued on September 26, 2018, valid until September 25, 2023).

The activity of acid phosphatase was determined by a method based on the ability of acid phosphatase to hydrolyze the ether bond. The action of the enzyme serum sodium beta-glycerophosphate to be hydrolyzed with the subsequent release of inorganic phosphorus, aspartate aminotransferasa and alanine aminotransferasa was determined by the Reitman-Frenkel method, bilirubin [17] by diasore.

All animal experiments were conducted according to with the recommendations of ARRIVE and the British Animal Act 1986 and Directive 2010/63 / EU on the protection of animals for scientific investigation.

Statistical processing of the results was performed using standard computer programs to determine the arithmetic mean (M), the statistical error of the arithmetic mean $(\mathrm{m})$, which was limited of indicators from 0,5 to 0,21 units, the probability of the difference (p) between the arithmetic means of two variation series on the confidence factor for the mean difference $(t)$, the correlation coefficient ( $r$ ). The difference between the two values was considered probable for $*-p \leq 0,05 ; * *-p \leq 0,01$; $* * *-\mathrm{p} \leq 0,001$

\section{Results}

From the results, given in Table 1, it is seen that after the use, in control and experimental groups of cows during the dry period of the preparations of acidum succinicum, the activity of alkaline phosphatase in their body did not change. The data obtained indicate the absence of pathology in the mineral metabolism of cows after calving.

Table 1

The activity of alkaline, acid phosphatases, alanine and aspartate aminotransferases and bilirubin in the blood of cows after calving under the influence of succinic acid $\mathrm{M} \pm \mathrm{m}, \mathrm{n}=10$

\begin{tabular}{|c|c|c|c|}
\hline \multirow[t]{2}{*}{ Indicator } & \multicolumn{3}{|c|}{ Groups of caws } \\
\hline & $\begin{array}{c}\text { acidum succinicum } \\
\text { (before administration) }\end{array}$ & $\begin{array}{l}\text { acidum succinicum } \\
\text { (after administration) }\end{array}$ & control \\
\hline Alkaline phosphatase units/l & $100.53 \pm 0.05$ & $100.48 \pm 0.45$ & $\frac{102.65 \pm 0.77}{100.49 \pm 0.45}$ \\
\hline Acid phosphatase units/l & $4.01 \pm 0.08$ & $4.75 \pm 0.10^{*}$ & $\frac{3.71 \pm 0.09}{4.75 \pm 0.10^{* * *}}$ \\
\hline AlAT units/l (10-30) & $25.85 \pm 0.19$ & $28.95 \pm 0.21^{*}$ & $\frac{25.36 \pm 0.66}{28.95 \pm 0.21 *}$ \\
\hline AcAT units/1 (10-50) & $38.66 \pm 0.12$ & $29.81 \pm 0.14 * * *$ & $\frac{33.31 \pm 0.44}{49.03 \pm 0.14 * * *}$ \\
\hline Ritis factor & 0.67 & $0.97 *$ & $\underline{0.73}$ \\
\hline Bilirubin mkmoll/l $(0,3-7)$ & $5.88 \pm 0.08$ & $3.76 \pm 0.16^{* * *}$ & $\frac{2.16 \pm 0.15}{4.77 \pm 0.16^{* * *}}$ \\
\hline
\end{tabular}


After the use of acidum succinicum in the body of cows of the experimental group, the activity of acid phosphatase increased by $18,5 \pm \%(\mathrm{p} \leq 0,05)$, while in the cows of the control group the activity of this enzyme increased by $28,0 \pm \%(p \leq 0,001)$. The obtained data indicate the beginning of the development of the inflammatory process in the uterine endometrium of cows of the control group, which confirms the statement that the increase in acid phosphatase activity in the uterine endometrium of cows after birth is a marker of the inflammatory process.

Study of the activity of alanine and aspartate aminotransferasa provides informative diagnostic data on the condition of the liver. In the body of cows of the experimental group, after the use of acidum succinicum, the activity of alanine aminotransferase increased by $12,0 \pm \%$ $(\mathrm{p} \leq 0,05)$, and the activity of aspartate aminotransferasa, by contrast, decreased by $30,0 \pm \%(\mathrm{p} \leq 0,001)$, which indicates a positive effect of the drug on hepatocytes of the liver. Confirmation of this is the de Ritis coefficient, which increased 1,4 times $(p \leq 0,05)$.

The data obtained show that cows of both groups were prone to the development of postpartum endometritis, but acidum succinicum, used after childbirth, prevented the development of inflammation in the uterine endometrium of cows of the experimental group.
In the body of cows of the control group, the activity of alanine and aspartate aminotransferases increased, respectively, by $14,0 \%(\mathrm{p} \leq 0,05)$ and $47,0 \%$ $(\mathrm{p} \leq 0,001)$ against a background of a decrease of 1,2 times $(p \leq 0,05)$ Ritis factor. The data obtained indicate damage to the liver hepatocytes of cows of the control group in the postpartum period, which may be a consequence of intoxication of their body in the last trimester of pregnancy.

A decrease in bilirubin content of $56,0 \%$ $(p \leq 0,001)$ in cows after the use of acidum succinicum and an increase in its content by 2,2 times $(\mathrm{p} \leq 0,001)$ in cows of the control group indicates liver disease, which accompanied by lesions of its parenchyma, which may be the result of intoxication of their body in the last trimester of pregnancy.

Thus, the use of acidum succinicum in cows after birth has a positive effect on the activity of enzymes in their body and ensures the course of their physiological reactions, which creates the basis for the involution of the uterus.

The course of calving and the post-calving period is decisive in the manifestation of sexual hunting cows and their fertilization and the development of subsequent pregnancy, and the insemination index decreased by $40,0 \pm \%(p \leq 0,05)$ against the corresponding indicators of cows of the control group (Table 2).

Indicators of reproductive function of cows after the use of acidum succinicum, $M \pm m, n=10$

Table 2

\begin{tabular}{|c|c|c|c|}
\hline Group of caws & Service period, days & Insemination index & Diseases of cows with mastitis \\
\hline $\begin{array}{c}1 \text { group } \\
\text { acidum succinicum }\end{array}$ & $80.0 \pm 2.0^{* *}$ & $1.3^{*}$ & 1 «++» \\
\hline $\begin{array}{c}2 \text { group } \\
\text { Control group }\end{array}$ & $121.0 \pm 8.0$ & 1.8 & 1 ? \\
\hline
\end{tabular}

Note: $*-p \leq 0,05 ; * *-p \leq 0,01$, compared with the control group

Stimulation of the immune system of cows with acidum succinicum after calving prevented the development of mastitis. One cow in the control group was diagnosed with a case of subclinical mastitis.

\section{Discussion of research results}

In this section of the article it is necessary: Application of acidum succinicum to cows after calving is a simple and affordable method. Acidum succinicum had a positive effect on enzyme activity and the course of uterine involution. Thus, in the body of cows of the experimental group, after the use of acidum succinicum, the activity of alanine aminotransferase increased, and the activity of aspartate aminotransferase, on the contrary, decreased, indicating a positive effect of the drug on hepatocytes, consistent with the instructions on the drug [16] and confirmation of this is the de Ritis coefficient, which increased 1,4 times. Reduction of the duration of the service period by 41 days, and reduction of the insemination index by $40,0 \%$ against the corresponding indicators of cows of the control group is consistent with the research of $[4,7,14,15]$. on the positive effect of immunomodulatory drugs on the body of cows used for calving cows.
The limitation of the research was the impossibility of studying the action of succinic acid during the gestation period of cows and the use of a combination of drugs that adversely affect the quality and safety of dairy products.

Prospect of further research on the use of acidum succinicum in cows is to study its effects during the start-up period and insemination of cows.

\section{Conclusions}

Thus, acidum succinicum, applied to cows after calving, prevents the development of inflammation of the reproductive system, helps to restore reproductive function, reduces the duration of the service period to $80,0 \pm 2,0$ days, and the insemination index to 1,3 .

Restrictions, at the conduct research on the use of acidum succinicum in cows, we are not set.

\section{Conflict of interest}

The authors declare that they have no conflicts of interest.

Financing

The study was performed without financial support. 


\section{References}

1. Feren, N. M., Yaremchuk, V. R. (2015). Role of lipid peroxidation and antioxidant system in liverin the pathogenesis of experimental pneumonia and immobilizationstress and correction of their violations by corvitin. Medychna khimiia, 17 (1), $100-103$.

2. Pavliuk, M. V. (2017). Tekhnolohiia vidtvorennia silskohospodarskykh tvaryn. Ahrarna osvita, 140.

3. Nekrasov, G. D., Sumanova, I. A. (2007). Akusherstvo, ginekologiya i biotekhnika vosproizvodstva zhivotnykh. Barnaul: Izd-vo AGAU, 204.

4. Koreiba, L. V., Holub, A. A., Melnyk, Yu. O. (2016). Efficiency of treatment of postpartum endometritis in cows. Modern directions of theoretical and applied researches. Available at: https://www.sworld.com.ua/konfer42/178.pdf

5. Slypaniuk, O. V. (2013). Osoblyvosti protsesiv peroksydnoho okysnennia lipidiv i stan nespetsyfichnoi rezystentnosti u tilnykh koriv ta yikh teliat za dii vitaminiv A, D, E, selenu ta interferonu. Zahalna patolohiia ta patolohichna fiziolohiia, 8 (1).

6. Hevkan, I. I., Syrvatka, V. Ya., Shtapenko, O. V. (2016). Vyvchennia kompleksnoho vplyvu liposomalnykh preparativ nanochastynok Arhentumu i orhanichnykh mikroelementiv na biokhimichni pokaznyky krovi ta efektyvnist likuvannia endometrytiv u koriv koriv. Biolohiia tvaryn, 18 (3), 124.

7. Fedorenko, S. Ya., Sklyarov, P. M., Koshevoy, V. P. (2017). Efektyvnist terapiyi koriv ta kiz z hipohonadyzmom za vykorystannya nanopreparatu «Kaplaestrol + OV». Naukovyy visnyk Lviv'koho natsionalnoho universytetu veterynarnoyi medytsyny ta biotekhnolohiy im. S. Z. Hzhytskoho, 19 (82).

8. Semerunchyk, A. (2015). Osnovni aspekty likuvannia koriv, khvorykh na metryt Veterynarna medytsyna Ukrainy, 9 (235). Available at: https://www.biotestlab.ua/articles/osnovni-aspekti-likuvannia-oriv-khvorikh-na-metrit/

9. Fedotova, E. A. (2016). Vliyanie «BSH-VIT» na profilaktiku poslerodovoy patologii u korov. Molodezh i nauka, 3.

10. Semenyuk, Ya. S. (2021). Synchronization of the stage of sexual arousal andinsemination of cows. Zhytomyr, 37. Available at: http://ir.znau.edu.ua/bitstream/123456789/11136/1/Semenyuk_Ya\%20S_211_2021.pdf

11. Gilbert, R. O. (2016). Management of Reproductive Disease in Dairy Cows. Veterinary Clinics of North America: Food Animal Practice, 32 (2), 387-410. doi: http://doi.org/10.1016/j.cvfa.2016.01.009

12. Green, A. S., Fascetti, A. J. (2016). Meeting the Vitamin A Requirement: The Efficacy and Importance of $\beta$-Carotene in Animal Species. The Scientific World Journal, 2016, 1-22. doi: http://doi.org/10.1155/2016/7393620

13. Hemingway, R. G. (2003). The influences of dectary intakes and supplementation with selenium and vitamin E on reproduction diseases and reproductive efficiency in caule and sheep. Veterinary Research Communications, 27 (2), 159-174. doi: http://doi.org/10.1023/a:1022871406335

14. Buso, R. R., Campos, C. C., Santos, T. R., Saut, J. P. E., Santos, R. M. (2016). 0122 Retained placenta and subclinical endometritis: Prevalence and relation with reproductive performance in crossbred dairy cows. Journal of Animal Science, 94 (5), $57-$ 57. doi: http://doi.org/10.2527/jam2016-0122

15. Gordon, I. R. (2017). Reproductive Technologies in Farm Animals. CABI, 342. doi: http://doi.org/10.1079/9781780646022.0000

16. Burshtynova kyslota Available at: https://preparat.com.ua/ua/bad/Yantarnaya-kislota

17. Vlizlo, V. V., Fedoruk, R. S. Ratych, I. B. (2012). Laboratorni metody doslidzhen' u biolohiyi, tvarynnytstvi ta veterynarniy medytsyni. Lviv: Vydavnytstvo «Spolom», 764.

Received date 06.05.2021

Accepted date 04.06.2021

Published date 30.06.2021

Fedonyuk Larysa, Doctor of Medical Sciences, Professor Department of Medical Biology, I. Horbachevsky Ternopil National Medical University, Voli ave., 1, Ternopil, Ukraine, 46001

Stravskyy Yaroslav, Doctor of Veterinary Sciences, Senior Researcher, Department of Medical Biology, I. Horbachevsky Ternopil National Medical University, Voli ave., 1, Ternopil, Ukraine, 46001

Khavtur Vira, Postgraduate Student, Senior Laboratory Assistant, Department of Medical Biology, I. Horbachevsky Ternopil National Medical University, Voli ave., 1, Ternopil, Ukraine, 46001

Sachuk Roman, Doctor of Veterinary Sciences, Senior Researcher, Department of Ecology, Geography and Tourism, Rivne State University of the Humanities, S. Bandery str., 12, Rivne, Ukraine, 33028

*Corresponding author: Stravskyy Yaroslav, e-mail: stravskyy@tdmu.edu.ua 